\title{
Hypothalamic orexin A expression and the involvement of AMPK and PPAR-gamma signalling in energy restricted dairy cows
}

\author{
Björn Kuhla, Solvig Görs and Cornelia C. Metges
}

Research Unit Nutritional Physiology »Oskar Kellner«, Leibniz Institute for Farm Animal Biology (FBN), Dummerstorf, Germany

\begin{abstract}
A number of circuits controlling feed intake have been identified in rodents in which circulating dietary metabolites are detected by the brainstem and the hypothalamus converting these input signals to anorexic responses. Dietary metabolites used by dairy cows, however, are not identical with those of rodents calling for the elucidation of feedingrelated pathways in ruminants. In the present study we examined potentially relevant plasma metabolites and hypothalamic signalling pathways in ad libitum and restrictively fed early lactating dairy cows. $60 \mathrm{~h}$ feed energy restriction led to significantly increased non-esterified fatty acid (NEFA), Gln, Gly, His, and 3-Me-histine but decreased Asp, Asn, beta-Ala, Tyr, and Trp concentrations. In immunohistochemical studies, we found that feed energy restriction is associated with elevated numbers of parvocellular but not magnocellular orexin A neurons in the lateral, dorsomedial and posterior hypothalamic area. In parvocellular orexin A neurons we determined complete colocalisation with cFOS in energy restricted cows. In the majority of orexin A neurons we further found colocalisation with activated adenosine monophosphate activated kinase (AMPK) as well as with peroxisome proliferator-activated receptor-gamma (PPARY). Feed restriction also induced activation (phosphorylation) of AMPK and increased expression of PPAR $y$ when Western Blots were normalized to $\beta$-actin. These results suggest that orexin A associated with AMPK and PPARY signalling is involved in the control of energy homeostasis of dairy cows.
\end{abstract}

Keywords: dairy cow, hypothalamus, feed intake control, AMPK, orexin A, PPARY

\section{Zusammenfassung}

\section{Die hypothalamische Orexin A-Expression und die Beteiligung der AMPK- und PPAR-gamma-Signalwege bei energierestriktiv-gefütterten Milchkühen}

Zahlreiche, unterschiedliche Mechanismen, die die Futteraufnahme von Nagern kontrollieren, wurden bereits identifiziert. Dabei wirken unter anderem nutritive Metabolite auf Neurone im Hirnstamm und im Hypothalamus, in dessen Folge eine anorektische Antwort erzeugt wird. Da Kühe und Nager unterschiedliche nutritive Metabolite nutzen, bedarf es einer separaten Aufklärung futteraufnahmeregulierender Mechanismen bei Wiederkäuern. In der vorliegenden Studie untersuchten wir potentiell-relevante Plasmametabolite 
und hypothalamische Signalwege bei ad libitum und restriktiv gefütterten Kühen in der Frühlaktation. Eine 60-stündige Futterenergierestriktion führte zu einer Zunahme der Plasmakonzentration an nicht-veresterten Fettsäuren, Gln, Gly, His und 3-Methylhistidin sowie zu einer Abnahme von Asp, Asn, beta-Ala, Tyr und Trp. In immunhistochemischen Untersuchungen konnte gezeigt werden, dass eine Energierestriktion zu einer erhöhten Anzahl parvozellulärer, jedoch nicht magnozellulärer Orexin A-Neurone im lateralen, dorsomedialen und posterioren Hypothalamus führt. Bei energierestriktiv gefütterten Kühen stellten wir eine Kolokalisierung von parvozellulären orexin A Neuronen mit cFOS fest. In der Mehrzahl der Orexin A-Neurone fanden wir ferner eine Kolokalisierung mit phosphorylierter Adenosinmonophosphat-aktivierter Kinase (pAMPK) und mit PeroxisomProliferator-Aktivierten Rezeptor-gamma (PPARY). Western Blot-Studien ergaben, dass die Energierestriktion auch die Aktivierung (Phosphorylierung) von AMPK und eine erhöhte Expression von PPARy induzierte. Diese Ergebnisse lassen vermuten, dass in Orexin A-Neuronen der AMPK und der PPARY-Signalweg bei der Regulation der Energiehomeostase von Milchkühen beteiligt ist.

Schlüsselwörter: Milchkuh, Hypothalamus, Futteraufnahmeregulation, AMPK, Orexin A, PPARY

\section{Introduction}

Understanding the systems that govern feed intake of dairy cows is of high priority since animals considerably reduce their feed intake prior to parturition and reincrease it only slowly by the 6th week post partum (Ingvartsen \& Andersen 2000). Thus, high producing dairy cows ingest less nutrients and energy than they require for meeting energy demands of milk secretion at the onset of lactation The hypothalamus has long been thought to play a role in the control of energy homeostasis and feed intake. Orexin A is an orexigenic neuropeptide, which is specifically localized in neurons within the hypothalamus, including the lateral, the caudal, the perifornical, the dorsomedial, and the posterior hypothalamic area in rats and sheep (Nambu et al. 1999, Qi et al. 2008). Hypothalamic orexin A neurons project to the neuraxis to areas of the brainstem (Harrison et al. 1999, Zheng et al. 2005) that are involved autonomic functions. In rodents, the orexin A system is implicated in feeding, drinking, waking, arousal, activity, reward, and gastrointestinal processing (Zheng et al. 2005, Baird et al. 2009). For sheep it has been suggested that orexin may not have a direct role in appetite control because feed restriction did not affect preproorexin mRNA expression (Archer et al. 2002, lqbal et al. 2003). Since orexin is increasingly expressed during short photoperiods, recent studies suggested a role of orexin in the reproductive activation for seasonal breeding ewes (Archer et al. 2002, Zieba et al. 2011). Furthermore, numbers of orexin mRNA containing neurons of genetically selected lean and fat sheep were inversely correlated with adiposity and not feed intake, suggesting rather a role for orexin in the control of energy expenditure (Anukulkitch et al. 2009). However, measurements of preproorexin mRNA levels allow no conclusion on the presence of the biological-active form. Only post-translational modification by specific enzymatic cleavages results in orexin $A$ and orexin $B$ formation. The fact that orexin peptide plays a role in central orexigenic signalling also in ruminants has 
been shown by Sartin et al. (2001) who demonstrated that intracerebroventricular injection of orexin B increased feed intake in sheep.

The hypothalamic adenosine monophosphate activated kinase (AMPK), a serine/ threonine kinase has emerged as central signal transducer for orexigenic responses. For example, phosphorylation of AMPK stimulates expression of the orexigene agouti-related protein (AgRP) (Lee et al. 2005). Beside a number of metabolites and hormones also fasting conditions stimulate hypothalamic AMPK phosphorylation and central injection of AMPK activators increases food intake (Xue \& Kahn 2006, Minokoshi et al. 2008).

As another pathway, the peroxisome proliferator-activated receptor-gamma (PPARY) may be involved in signal transduction and transcription of orexigens (Sarruf et al. 2009). PPARy is mainly expressed in orexigenic AgRP and a-melanocyte stimulating hormone (a-MSH) neurons and localized in numerous hypothalamic areas (Sarruf et al. 2009). Application of synthetic PPARy agonists provoked increased feed intake in rodents (Festuccia et al. 2008) and cows (Smith et al. 2007). These observations have raised the possibility that central PPARy plays a role in the control of feed intake (Sarruf et al. 2009).

Unlike ewes, cows do not breed during certain photoperiods only suggesting that orexin should not have a major role in photoperiodically controlled reproductive processes in the bovine. Whether orexin A protein is regulated in the bovine brain in response to different feeding levels, however, and whether orexin A neurons express AMPK or PPARY is not known. Therefore, the objectives of our study was to confirm the presence of orexin A protein in colocalisation with PAMPK and PPAR $y$ in the brain of ad libitum and feed restricted fed lactating cows.

\section{Materials and methods}

\section{Animals and feeding regimen}

All experimental procedures were conducted in accordance to the guidelines for the use of animals as experimental subjects of the State Government in Mecklenburg-West Pommerania, Germany (Registration No. LALLF M-V/TSD/7221.3-2.1-025/06). Ten first-lactating Holstein dairy cows (27 to 28 months of age) were fed a total mixed ration (TMR) consisting of corn and grass silage, hay and concentrate (6.4 MJ NE// kg DM) ad libitum twice daily (4.30a.m. and 11.30 a.m.) with free access to water. Feed stuff was offered in a feed bin which was connected to an electronic registration device that allowed to record daily food intake $24 \mathrm{~h}$. Cows were healthy and not pregnant. Cows were milked twice daily (4.00 a.m. and 3.30 p.m.). Prior to the feeding experiment, the daily milk yield of the ad libitum group was $23.4 \pm 2.8 \mathrm{~kg}$, that of the restricted group was $20.9 \pm 3.1 \mathrm{~kg}$ ( $P=0.25$, t-test).

Five cows were continuously fed ad libitum with TMR (ad libitum group) and five cows were TMR deprived for $60 \mathrm{~h}$ before slaughter but had access to short chopped wheat straw (3.0 MJ $\mathrm{NE}_{\mathrm{L}} / \mathrm{kg} \mathrm{DM}$; energy, macro- and micronutrient restriction) to prevent rumen collapse (restricted group). Early lactating animals in the ad libitum fed group were 53 $\pm 24 \mathrm{~d}$ and in the restricted group $42 \pm 24 \mathrm{~d}$ in milk $(P>0.5)$. The average daily energy intake corresponded to $110.2 \pm 11.2 \mathrm{MJ}$ $\mathrm{NE}_{\mathrm{l}}$ for the ad libitum and $18.0 \pm 1.1 \mathrm{MJ} \mathrm{NE}_{\mathrm{l}}$ for the ad libitum group, respectively $(P<0.01$, t-test). At the day of slaughter, all cows were withdrawn from feed at $6.30 \mathrm{a} . \mathrm{m}$. and weighed. The mean body weight in the ad libitum and restricted group was $529 \pm 29$ and $485 \pm 38 \mathrm{~kg}$, 
respectively ( $P=0.1$, t-test). Animals were slaughtered in the institutional slaughterhouse at 7.30 a.m. by exsanguinations following captive bolt stunning. The head was instantaneously displaced and the skullcap was opened at the dorsal side; the dura mater was left aside and the brain withdrawn after secession from the pituitary gland, the optic nerves and the brain stem. The latter was used in the legally ordered Bovine Spongiform Encephalopathy (BSE) test. The time elapsed from head displacement to brain withdrawal was approximately 10-15 min. The isolated brain was immediately chilled on ice and a frontal section was made bounding anterior at the optic chiasm and posterior at the mammillary bodies. The hypothalamic region was isolated by two diagonal sections ranging from the fornix directly to the most ventrolateral side of the optic tract. The tissue was liberated of external blood vessel network, cut along the median axis, and halves were snap frozen on an aluminium foil swimming on liquid nitrogen and further stored at $-80^{\circ} \mathrm{C}$. For the present study, the left hypothalamic hemispheres were crushed to a fine powder in a mortar containing liquid $\mathrm{N}_{2}$. Part of the tissue powder was used in a study published previously (Kuhla et al. 2007).

\section{Blood sampling and analysis of plasma metabolites}

Jugular blood samples were withdrawn in $9 \mathrm{ml}$ tubes containing EDTA. Blood samples were immediately placed on ice, centrifuged $\left(2000 \times \mathrm{g}, 4^{\circ} \mathrm{C}, 20 \mathrm{~min}\right)$ and the obtained plasma stored at $-80^{\circ} \mathrm{C}$ until further analysis. Plasma non-esterified fatty acids (NEFA), betahydroxybutyrate (BHBA), urea, and glucose concentrations were analysed using routine laboratory kits based on photospectrometrical methods. Briefly, glucose was measured by the glucose hexokinase assay (\#555-230, mtl diagnostics, Idstein, Germany), and plasma NEFA concentrations were determined by an acyl-CoA synthetase based assay (\#434-91795, Wako Chemicals, Neuss, Germany), BHBA in a NADH-forming assay (\#RB 1008, randox laboratories, Ardmore, UK), urea by \#LT-UR0050 (Labor+Technik E. Lehmann, Berlin, Germany), and free plasma amino acids after derivatisation with ortho-phthalaldehyde by HPLC equipped with a fluorescence detector as described recently (Kuhla et al. 2010).

\section{Immunohistochemistry}

For immunohistochemistry, the right hypothalamic hemisphere of three subjects fed ad libitum and three fed restrictively were available. Snap frozen tissue was cut on a freezing microtome $(10 \mu \mathrm{m})$. Sections were placed on slides, fixated in $4 \%$ paraformaldehyde/0.1 M PBS, and stored in cryo protection solution (0.1 M PBS containing $40 \%$ glycerol, $4 \%$ sucrose, $0.1 \% \mathrm{MgCl}_{2}$ ) at $-80^{\circ} \mathrm{C}$. Sections on slides were rinsed with $0.1 \mathrm{M} \mathrm{TBST}(\mathrm{pH} 7.8)$ and unspecific binding sites were blocked with normal goat and normal donkey serum (1:10) in $0.1 \mathrm{M}$ TBST supplemented with $0.5 \%$ Triton X100 (FERAK, Berlin, Germany) for $2 \mathrm{~h}$. Next, sections were incubated with polyclonal sheep IgGs to human orexin A (Acris, Hiddenhausen, Germany; $100 \%$ sequence homology to bovine) at $4^{\circ} \mathrm{C}$ for $16 \mathrm{~h}$, washed and subsequently incubated with AF488 labelled donkey-antisheep antibody (1:50, Invitrogen, Karlsruhe, Germany) at RT for 2 h. For colocalisation studies on the hypothalamus, rabbit-anti PPAR-gamma1/2 (ABR-Affinity BioReagents; Golden, CO, USA; antigen homolog to the bovine sequence except for Ser 296), pAMPKa (Thr 172) (Cell Signaling Inc., Danvers, MA, USA; highly conserved between mammalian species) and rabbitanti cFOS (Ab5; Calbiochem, Germany; antigen sequence is $100 \%$ homolog to the bovine 
sequence) were used and detected by incubation with Cy3 labelled goat-anti-rabbit antibody (1:50, Invitrogen, Karlsruhe, Germany) at RT for $2 \mathrm{~h}$. For controls, primary antibodies were omitted and each one section was incubated with a fluorescence-labelled secondary antibody only yielding no cellular staining. After intensive washing, slices were mounted with glycerol and analysed on a fluorescence microscope (Axioskop 40 HBO100, Zeiss Jena, Germany). In quantification studies, orexin A positive cells were counted in 6 slices per individual. Three different, non-overlapping areas (each $1 \mathrm{~mm}^{2}$ ) per slice were considered. The average of the 16 regions was used to calculate group means, with a final $n=3$. The cut-off between parvo ( 8$10 \mu \mathrm{m})$ and magnocellular ( $>20 \mu \mathrm{m})$ neurons in the bovine hypothalamus was defined earlier (Vierling 1957). Staining intensity was not considered.

\section{Western blot analysis}

Each $40 \mathrm{mg}$ tissue powder was extracted in $0.4 \mathrm{ml}$ lysis buffer in $50 \mathrm{mM}$ TBS (pH 7.6) containing $1 \mathrm{mM}$ EDTA, $100 \mathrm{mM} \mathrm{NaF}, 1 \mathrm{mM} \mathrm{NaVO} 4^{\prime} 0.5 \%$ DOC, $0.1 \%$ SDS, $1 \%$ Igepal. Extracts were centrifuged at $12000 \times \mathrm{g}$ for $10 \mathrm{~min}$ at $4{ }^{\circ} \mathrm{C}$. Protein content was assayed by BCA using BSA as reference. Equal amounts of protein were treated with Laemmli buffer, boiled for 5 min, loaded on SDS gels, and electrotransferred to nitrocellulose. Blots were blocked in Roti-Block (ROTH, Karlsruhe, Germany) containing $3 \%$ BSA for $1 \mathrm{~h}$ at RT under shaking, rinsed with 0.1 M TBST ( $\mathrm{pH}$ 7.8) and the primary antibody (each 1:1000) was incubated for $16 \mathrm{~h}$ at $4^{\circ} \mathrm{C}$. Beside the above mentioned pAMPKa and PPAR $y$ antibodies, monoclonal antibody against AMPKa (clone 23A3) was from Cell Signaling Inc. (Danvers, MA, USA) and polyclonal rabbit-anti $\beta$-actin (H-300; SC10731) was from Santa Cruz Biotechnology (Santa Cruz, CA, USA), polyclonal. All antibodies used detect highly conserved epitopes between mice and bovine species. After 5 washing steps in TBST, horseradish peroxidase-labelled secondary antibodies (1:1000) were applied for $2 \mathrm{~h}$ at room temperature. After washing, blots were developed on hyperfilmes using Enhanced Chemiluminescence $(E C L)$ reaction. Hyperfilm were scanned and digital images were analysed by ImageJ 1.4 software ( $\mathrm{NIH} \mathrm{2010)} \mathrm{and} \mathrm{are} \mathrm{representative} \mathrm{of} \mathrm{three} \mathrm{independent} \mathrm{experiments.}$

\section{Analysis of $m R N A$}

For real-time RT-PCR, $100 \mathrm{mg}$ of powdered brain tissues were homogenized by use of a teflon homogenizer in $1 \mathrm{ml}$ TRIZOL according to the manufacture instructions (Life Technologies, Basel, Switzerland). The obtained RNA was evaluated by $A_{260}: A_{280}$ ratio at an Implen Nanophotometer (Implen $\mathrm{GmbH}$, Munich, Germany) and was within a range of 1.6-1.9. Presence of $18 \mathrm{~S}$ and $28 \mathrm{~S}$ bands was confirmed by agarose gel electrophoresis and ethidium bromide staining. RNA was reverse transcribed using random hexamers (Invitrogen, Karlsruhe, Germany) and M-MLV reverse transcriptase (Promega, Mannheim, Germany) in the presence of RNAse inhibitor (Promega, Mannheim, Germany). CDNA was purified with a purification kit (Roche Diagnostics, Mannheim, Germany). For real-time RT-PCR, purified cDNA, DNA Master SYBR Green I Kit (Roche Diagnostics, Mannheim, Germany) and the following primers were applied: for PPAR-gamma-1/2 (GI:25990189; exon 4-5): 5'-AAA GCG TCA GGG TTC CAC TAT-3' and 5'-ATC TCC GCT AAC AGC TTC TCC-3'; for 18S ribosomal RNA (GI:83321215): 5'-GAG AAA CGG CTA CCA CAT CCA A-3' and 5'-GAC ACT CAG CTA AGA GCA TCG A-3' (Sigma, Taufkirchen, Germany). Primer design was performed with primer3 software (Rozen \& Skaletsky 
2000). Real time reverse transcription was performed on a LightCycler instrument (Roche Diagnostics, Mannheim, Germany) using 40 cycles at $94^{\circ} \mathrm{C}$ for $15 \mathrm{~s}, 60^{\circ} \mathrm{C}$ (for $\beta$-actin), or $57^{\circ} \mathrm{C}$ (for PPAR-gamma), respectively for $10 \mathrm{~s}$ and $72^{\circ} \mathrm{C}$ for $20 \mathrm{~s}$. Fluorescence signals were recorded on-line during amplification and analysed by the $" 2^{-\Delta \Delta C T}$ method (Livak \& Schmittgen 2001). To confirm purity and size, PCR products were loaded on a $1.6 \%$ agarose gel and subsequent stained with ethidium bromide. PCR products were cut out and their identity confirmed by sequencing on a 3130 Genitic Analyzer (Hitachi, Tokyo, Japan). Data obtained are from two independent measurements per sample and are given as mean \pm SD.

\section{Statistical analysis}

For comparison of hypothalamic signals an unpaired t-test was performed. Statistical significance was defined when $P<0.05$.

\section{Results}

In order to characterize the metabolic state after feed energy restriction, plasma metabolite concentrations were determined in five lactating cows fed ad libitum TMR and after a $60 \mathrm{~h}$ feed energy restriction period (Table 1). Energy restriction provoked significantly increased NEFA, Gln, Gly, His, and 3-Me-His but decreased Asp, Asn, $\beta$-Ala, Tyr, and Trp concentrations, indicating the presence of an energy restricted state.

Next we examined whether $60 \mathrm{~h}$ feed energy restriction stimulated central orexigen $\mathrm{A}$ expression. Since there is no bovine brain atlas to clearly distinguish between hypothalamic nuclei, we investigated an area which includes the lateral, dorsomedial, and posterior hypothalamic nuclei, three regions classically implicated in feeding behaviour (Nambu et al. 1999). Counting orexin A stained neurons in these 3 areas revealed that orexin A expression in magnocellular neurons $(>20 \mu \mathrm{m})$ did not changed with feed energy restriction (means: $\mathrm{n}=13$ in ad libitum and $\mathrm{n}=16$ in restrictively fed animals; $P=0.5$. However, pronounced orexin A expression in parvocellular neurons $(\sim 8-10 \mu \mathrm{m})$ was observed only in energy restricted cows (means: $n=18$ in ad libitum and $n=59$ in restrictively fed cows $(P<0.01$; Figure 1$)$.

Staining for cFOS was observed in hypothalamic nuclei in both ad libitum and restrictively fed cows. Double labelled immunohistochemistry revealed colocalisation of cFOS in parvocellular orexin A neurons of the lateral, dorsomedial, and posterior hypothalamic area, which was more present in feed restricted animals ( $100 \%$ colocalisation) as compared with ad libitum fed cows ( $45 \%$ colocalisation; Figure 2$)$.

Furthermore, parvocellular neurons of the posterior, dorsomedial and lateral hypothalamic area colocalised with phospho-AMPKa (Thr172) in $\sim 85 \%$ of orexin A cells and with PPARY in approximately $90 \%$ of orexin A neurons (Figure 3), in both in ad libitum and in restrictively fed cows.

To test the overall (within the orexin A but also within other orexigenic systems) effect of feed deprivation on AMPK activation, Western blots probed with pAMPKa antibody were performed and normalized against total AMPKa. Even though equal amounts of protein were loaded, it appears that AMPKa immunoreactivity was lower in the restricted group while that of pAMPKa was comparable between groups (Figure 4). However, the ratio of pAMPK:AMPK raised to $140 \%$ after feed deprivation $(P<0.002)$. 
Table 1

Plasma metabolite concentrations of five lactating cows fed ad libitum and after a $60 \mathrm{~h}$ feed energy restriction period. Data are represented in $\mu \mathrm{M}$ as mean \pm SD and evaluated statistically using the paired t-test.

\begin{tabular}{|c|c|c|c|c|c|}
\hline \multirow[t]{2}{*}{ Metabolite } & \multicolumn{2}{|c|}{ Ad libitum } & \multicolumn{2}{|c|}{ Restriction } & \multirow[t]{2}{*}{$P$} \\
\hline & Mean & SD & Mean & SD & \\
\hline NEFA & 84.7 & 15.2 & 594.7 & 255.6 & 0.028 \\
\hline Glucose & 3685 & 225 & 3645 & 189 & 0.356 \\
\hline BHBA & 855 & 251 & 530 & 16 & 0.075 \\
\hline Urea & 3483 & 868 & 2378 & 545 & 0.272 \\
\hline Asp & 4.2 & 0.5 & 1.6 & 1.0 & 0.029 \\
\hline Glu & 38.1 & 7.8 & 27.1 & 5.9 & 0.078 \\
\hline Cys & 40.2 & 6.3 & 43.2 & 6.7 & 0.653 \\
\hline Asn & 36.7 & 7.3 & 28.5 & 5.1 & 0.011 \\
\hline Ser & 67.7 & 4.5 & 69.0 & 8.0 & 0.742 \\
\hline Gln & 239.1 & 28.4 & 282.0 & 36.2 & 0.037 \\
\hline $\mathrm{His}$ & 44.7 & 7.8 & 45.7 & 8.1 & 0.032 \\
\hline Gly & 231.5 & 60.8 & 346.0 & 80.1 & 0.026 \\
\hline Thr & 75.1 & 10.7 & 60.0 & 7.5 & 0.063 \\
\hline Cit & 51.8 & 8.1 & 63.1 & 19.2 & 0.253 \\
\hline$\beta$-Ala & 4.7 & 1.2 & 2.8 & 0.5 & 0.017 \\
\hline Arg & 73.2 & 14.9 & 85.5 & 19.8 & 0.105 \\
\hline 3-Met-His & 5.6 & 2.4 & 12.7 & 3.6 & 0.046 \\
\hline Ala & 178.1 & 34.6 & 202.2 & 19.5 & 0.079 \\
\hline Car & 11.0 & 2.4 & 8.4 & 1.4 & 0.087 \\
\hline Tau & 34.5 & 4.7 & 31.8 & 6.6 & 0.558 \\
\hline GABA & 0.8 & 1.7 & 0.3 & 0.7 & 0.647 \\
\hline Tyr & 48.1 & 6.2 & 27.6 & 4.8 & 0.007 \\
\hline$a-A B A$ & 15.5 & 2.3 & 16.7 & 2.7 & 0.492 \\
\hline Val & 187.1 & 24.1 & 163.8 & 52.3 & 0.214 \\
\hline Met & 17.2 & 3.3 & 16.7 & 4.0 & 0.779 \\
\hline Trp & 40.0 & 4.9 & 30.1 & 2.1 & 0.034 \\
\hline Phe & 38.9 & 5.6 & 39.5 & 7.2 & 0.787 \\
\hline Ile & 93.0 & 11.4 & 89.6 & 21.0 & 0.568 \\
\hline Orn & 34.2 & 8.2 & 36.6 & 7.3 & 0.513 \\
\hline Leu & 98.3 & 16.9 & 118.5 & 38.7 & 0.215 \\
\hline Lys & 62.2 & 14.9 & 74.7 & 19.2 & 0.115 \\
\hline Hy-Pro & 9.2 & 1.8 & 10.5 & 2.4 & 0.396 \\
\hline Pro & 53.4 & 9.2 & 48.1 & 17.4 & 0.615 \\
\hline
\end{tabular}

Next we determined the overall expression of PPARy in response to energy restriction. Western blot analysis revealed a slightly elevated PPAR $1 / 2$ expression (1.2-fold; $P<0.05)$ after feed restriction when normalized to $\beta$-actin (Figure 5). However, PPAR $1 / 2$ mRNA expression evaluated relative to $18 \mathrm{~S}$ mRNA was not increased in the restriction group (Figure 5). 

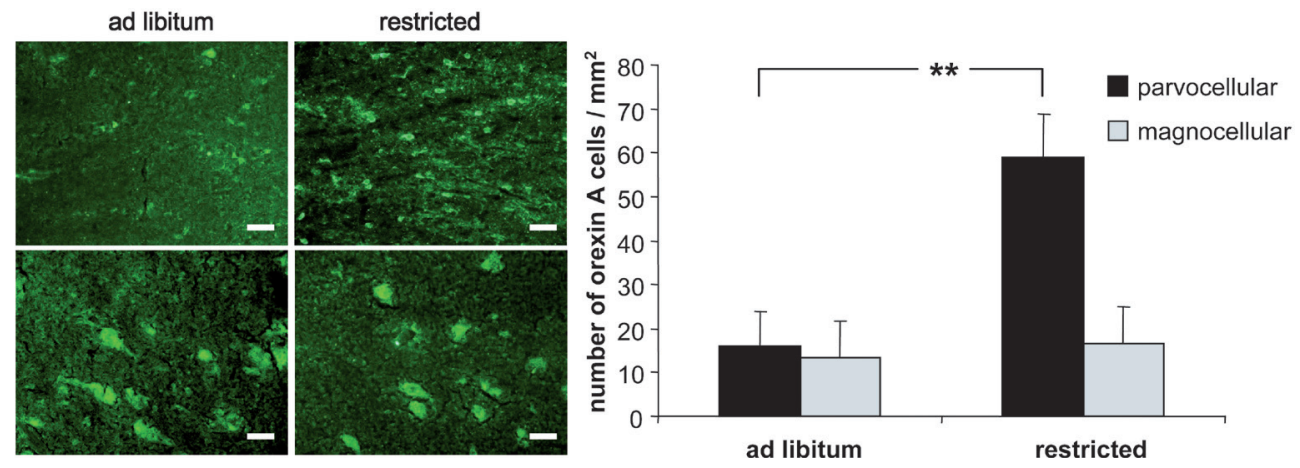

Figure 1

Analysis of orexin A in the posterior, dorsomedial and lateral hypothalamus of ad libitum and feed deprived dairy cows. Representatives from the posterior hypothalamic area (left hand site) show orexin A immunoreactive parvo $(\sim 8-10 \mu \mathrm{m})$ and magnocellular neurons $(>20 \mu \mathrm{m})$ of ad libitum and restrictively fed cows. The white bars within images indicate $20 \mu \mathrm{m}$. At the right, numbers of orexin A positive cells per $\mathrm{mm}^{2}$ were counted in the posterior, dorsomedial, and lateral hypothalamic area in 6 different slices per individual. Three individuals per feeding group were evaluated. The number of parvocellular neurons is displayed in black bars while numbers of magnum cell types are displayed in gray bars. The values are means+SD ( $n=3$ per group) and ${ }^{* *}$ indicates $P<0.01$; t-test.
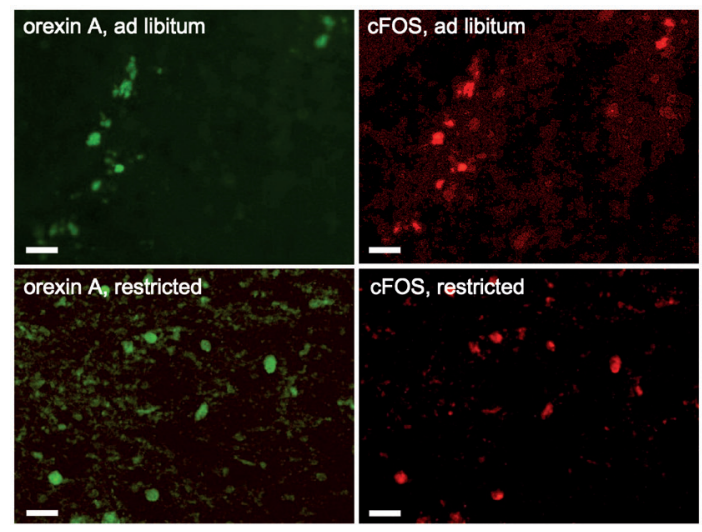

\section{Figure 2}

Fluorescence double staining of orexin A (green) and cFOS (red) ad libitum and energy restrictively fed dairy cows. Representatives from the lateral hypothalamic area are shown. The majority of neurons show diffuse cytoplasmic and nuclear staining for CFos. Merge images depict colocalisation of orexin A and cFOS (right) in parvocellular neurons (arrows). The asterisks indicate orexin A neurons without cFOS colocalization observed in ad libitum fed cows. Scale bar within images indicates $20 \mu \mathrm{m}$. At the right, the percentage (mean+SD; $n=3$ per group) of orexin A neurons expressing (FOS are displayed in ad libitum and restrictively fed cows. Asterisks indicate $P<0.01$; t-test. 

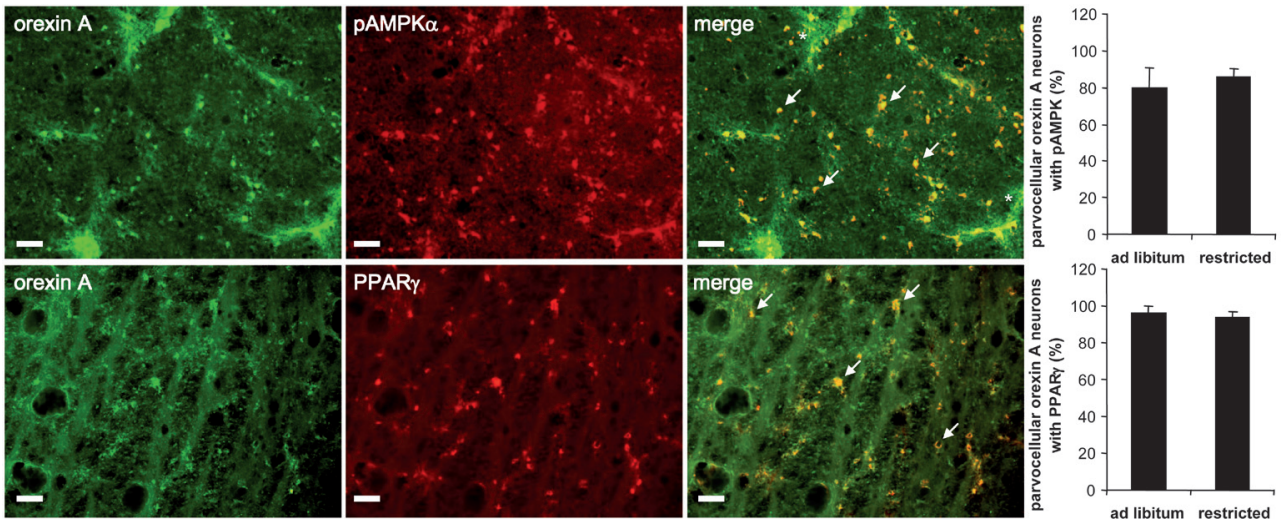

Figure 3

Colocalization of orexin A (green, top) and pAMPKa (Thr172) (red, top) and between orexin A (green, bottom) and PPARY (red, bottom). Representatives from the lateral hypothalamic area are shown. Merge images depict colocalisation of pAMPK (top right) and PPARy (bottom right) each with parvocellular orexin A neurons (arrows). The asterisks indicate orexin A fibres. Scale bar within images indicate $40 \mu \mathrm{m}$. At the right, the percentage (mean+SD, $n=3$ per group) of orexin A neurons colocalizing with pAMPK and PPAR $\gamma$, respectively, are displayed in ad libitum and restrictively fed cows. No differences between groups were observed.

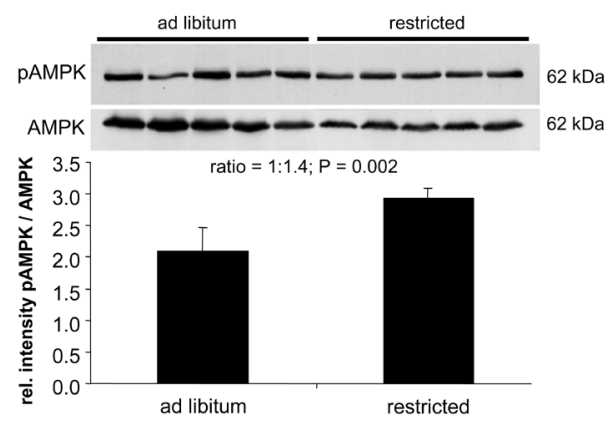

Figure 4

AMPKa (Thr 172) phosphorylation in hypothalamic tissue of ad libitum and restrictively fed dairy cows. Brain extracts were electrophoresed on a $10 \%$ SDS-gel and subsequently immunoblotted. A representative blot is shown. For densitometrical analysis pAMPKa (Thr 172) immunoreactivity was normalized to AMPKa. Data are presented as mean $+S D$ ( $n=5$ per group).
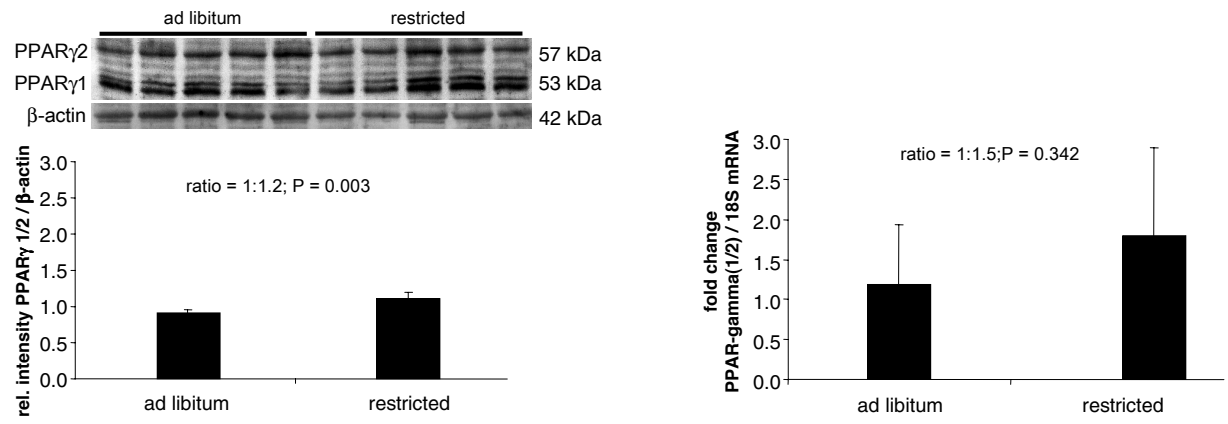

Figure 5

PPAR-gamma $1 / 2$ protein and mRNA expression. PPAR-gamma1/2 protein was analyzed by Western blot relative to $\beta$-actin. The band located approx. $1 \mathrm{kDa}$ above PPAR-gamma1 represents the phosphorylated form. Expression of PPAR-gamma1/2 mRNA was measured relative to 185 by using the $12^{-\triangle \Delta C T}$ method" (Livak \& Schmittgen 2001). Both, mRNA and protein analyses were done in duplicates and are depicted as means+SD ( $n=5$ per group). 


\section{Discussion}

Macronutrients such as glucose, fatty and amino acids may influence feeding behaviour in dairy cows. For example, feeding a high protein diet increases dry matter intake (Law et al. 2009), intravenous infusion of fatty acids reduce feed intake (Bareille et al. 1996) and hypoglycemia is usually associated with increased feed intake during early lactation. In response to short-term feed restriction (up to 3 days) it has been shown that plasma NEFA concentration increase while plasma glucose remains constant in mid-lactating (Oikawa et al. 2006) or non-lactating (Mohamed et al. 2004) dairy cows. The present study confirms these earlier findings for cows being in mid-lactation. In feed deprived early lactating cows ( $55 \pm 8$ days in milk), however, a rapid decline of plasma glucose can be observed (Chelikani et al. 2004), but this is probably owned to the prevailing glucose deficiency in early lactation. After long-term fasting ( $\geq 3$ days), cows also exhibit elevated BHBA concentrations (Mohamed et al. 2004, Oikawa et al. 2006), either originating from incomplete fatty acid oxidation or from ketogenic amino acids. Here we observed a trend towards decreasing BHBA concentration after the $60 \mathrm{~h}$ restriction period presumably attributed to a diminished BHBA supply from the rumen wall. Fasting for 6 days provoked a significant increase of plasma Leu and Phe and decrease of plasma Ser of dairy cows (Baird et al. 1972). In our study we did not observe changing Ser levels but increased plasma Gln, His, Me-His, Gly, which likely originate from protein breakdown in splanchnic tissue and skeletal muscle. Moreover, Trp, Tyr, Asp, and $\beta$-Ala were found in diminished concentrations after feed restriction. As our finding corresponds to data obtained from $24 \mathrm{~h}$ fasted cows (Ndibualonji et al. 1992) it seems likely that falling concentrations of these amino acids are a consequence of reduced supply from the rumen and their use for gluconeogenesis (glucogenic amino acids only).

Orexin positive neurons are primarily localized in the lateral, the perifornical nucleus, the dorsomedial, and the posterior hypothalamic nucleus. This observation is very similar for rats (Nambu et al. 1999) and sheep (Qi et al. 2008). Comparable studies for the bovine brain, however, do not exist. Since there is no bovine brain atlas for an unambiguous assignment of these areas in the cow hypothalamus, we focused in our studies on a transverse plane which includes the lateral, the dorsomedial, and the posterior hypothalamic area. Without exact bordering between these three areas, we found high density of parvocellular and magnocellular orexin A perikarya in all of these nuclei. Although food intake-related differences between parvocellular and magnocellular neurons of sheep has been described (Chaillou et al. 2000), its physiological meaning is far from clear.

However, here we report that the number of parvocellular but not of magnocellular orexin A neurons increased after feed restriction. Our result is comparable with earlier findings describing that FOS immunoreactivity in the paraventricular nucleus of unfed sheep has only been localized in the parvocellular but not in the magnocellular system (Chaillou et al. 2000). Furthermore, our result shows that orexin A protein is differentially expressed in the brain of a ruminating species after feed energy restriction, suggesting a role for the orexin A peptide in the control of feed intake. This does not exclude that orexin $A$ in the bovine regulates also other physiological processes such as arousal, drinking, sleeping, activity, and gastrointestinal processing as it does in sheep or rodents (Zheng et al. 2005, Baird et al. 2009).

Since orexin A expression was observed distinct in energy restricted animals and orexin A parvocellular neurons had colocalised with cFOS, these results further suggest that orexin 
A neurons were activated by the feed energy restriction stimulus. Our results are consistent with orexin A expression studies performed in rodents (Zheng et al. 2005, Baird et al. 2009) showing that orexin $A$ is a endogenous neurotransmitter which responds to hunger. Our data also support the Sartin study (Sartin et al. 2001) who described an orexigenic effect of orexin in sheep.

PPAR $\gamma$ has found to be widely expressed in the hypothalamus of rodents, particularly in orexigenic AgRP neurons, suggesting a potential role of PPARy in controlling feed intake (Sarruf et al. 2009) although short-term fasting (24 h) did not change hypothalamic PPARY1 expression in rats (Wiesner et al. 2004). Here we report for the cow hypothalamus that also the majority of parvocellular orexin A containing neurons of fed restricted cows expresses PPAR $y$, and that feed energy restriction increases hypothalamic expression of PPAR $y$ at the protein but not the mRNA level. However, by using whole hypothalamic extracts, increased PPARY expression may also occur in other hypothalamic nuclei than just the orexin A system of the three hypothalamic areas investigated. However, the latter assumption deserves further studies. Nevertheless, our results demonstrate the potential involvement of the PPAR $\gamma$ pathway in orexigenic signalling. Since NEFA are known as a ligand for PPAR $\gamma$ binding, elevated plasma NEFA levels occurring in response to feed energy restriction may account for the increased hypothalamic PPARy expression. However, recent findings indicates that less PPARy but rather PPARa may be involved in the control of feed intake in rodents since administration of a PPARa agonist into the hypothalamus increased PPARa target genes and increased food intake (Chakravarthy et al. 2007).

A recent study demonstrated for the rat brain that orexigenic AgRP neurons are colocalised with AMPK (Claret et al. 2007). In the present study we show that also parvocellular orexin A neurons co-localize with activated AMPK suggesting a potential role of the energy sensor AMPK in orexigenic signal transduction of orexin A neurons. Activation of hypothalamic AMPK increases food intake and vice versa fasting induces phosphorylation of AMPK in rodents (Xue \& Kahn 2006, Minokoshi et al. 2008). Also, feed-deprivation in dairy cows induces upregulation of hypothalamic 5-aminoimidazole-4-carboxamide ribonucleotide formyltransferase/IMP cyclohydrolase (AICAR), an enzyme involved in the production of AMP and thus potentially involved in increased AMPK phosphorylation (Kuhla et al. 2007). Our present study extends this knowledge showing that the overall hypothalamic ratio of pAMPK/AMPK also increases with feed deprivation although it seems that this is to explain by decreased AMPK expression after feed deprivation. Since plasma glucose is not diminished in feed energy restricted cows, metabolites others than glucose, for example the imbalanced amino acid pattern or reduced BHBA levels might account for the increased pAMPK/AMPK ratio after feed restriction. However, Claret et al. (2007) have shown that AMPK acts not as a the solely sensor and integrator of energy homeostasis which supports the idea that also PPAR is involved in sensing and orexigenic signalling at least during times of feed energy restriction.

In conclusion, parvocellular orexin A neurons of the posterior, dorsomedial, and lateral hypothalamic area colocalise with AMPK and PPARY. In whole hypothalamic extracts, AMPK and PPARY proteins are clearly regulated after feed deprivation suggesting at least the involvement of PPARY and AMPK in orexigenic signalling in cows. 


\section{Acknowledgements}

This study was supported by the core budget of the Leibniz Institute for Farm Animal Biology (FBN), Germany. We thank Martina Pohlmann for her help and the Institute for Experimental Surgery (University of Rostock) for providing their microscopy techniques.

\section{References}

Anukulkitch C, Rao A, Pereira A, McEwan J, Clarke IJ (2010) Expression of genes for appetite-regulating peptides in the hypothalamus of genetically selected lean and fat sheep. Neuroendocrinology 91, 223-238

Archer ZA, Findlay PA, Rhind SM, Mercer JG, Adam CL (2002) Orexin gene expression and regulation by photoperiod in the sheep hypothalamus. Regul Pept 104, 41-45

Baird GD, Heitzman RJ, Hibbitt KG (1972) Effects of starvation on intermediary metabolism in the lactating cow. A comparison with metabolic changes occurring during bovine ketosis. Biochem J 128, 1311-1318

Baird JP, Choe A, Loveland JL, Beck J, Mahoney CE, Lord JS, Grigg LA (2009) Orexin-A hyperphagia: hindbrain participation in consummatory feeding responses. Endocrinology 150, 1202-1216

Bareille N, Faverdin P (1996) Lipid metabolism and intake behavior of dairy cows: effects of intravenous lipid and beta-adrenergic supplementation. J Dairy Sci 79, 1209-1220

ChaillouE, Baumont R, Tramu G, Tillet Y (2000) Effect offeeding on Fos protein expression in sheep hypothalamus with special reference to the supraoptic and paraventricular nuclei: an immunohistochemical study. Eur J Neurosci 12, 4515-4524

Chakravarthy MV, Zhu Y, López M, Yin L, Wozniak DF, Coleman T, Hu Z, Wolfgang M, Vidal-Puig A, Lane MD, Semenkovich CF (2007) Brain fatty acid synthase activates PPARalpha to maintain energy homeostasis. J Clin Invest 117, 2539-2552

Chelikani PK, Ambrose JD, Keisler DH, Kennelly JJ (2004) Effect of short-term fasting on plasma concentrations of leptin and other hormones and metabolites in dairy cattle. Domest Anim Endocrinol 26, 33-48

Claret M, Smith MA, Batterham RL, Selman C, Choudhury Al, Fryer LG, Clements M, Al-Qassab H, Heffron H, Xu AW, Speakman JR, Barsh GS, Viollet B, Vaulont S, Ashford ML, Carling D, Withers DJ (2007) AMPK is essential for energy homeostasis regulation and glucose sensing by POMC and AgRP neurons. J Clin Invest 117, 2325-2336

Festuccia WT, Oztezcan S, Laplante M, Berthiaume M, Michel C, Dohgu S, Denis RG, Brito MN, Brito NA, Miller DS, Banks WA, Bartness TJ, Richard D, Deshaies Y (2008) Peroxisome proliferator-activated receptorgamma-mediated positive energy balance in the rat is associated with reduced sympathetic drive to adipose tissues and thyroid status. Endocrinology 149, 2121-2130

Harrison TA, Chen CT, Dun NJ, Chang JK (1999) Hypothalamic orexin A-immunoreactive neurons project to the rat dorsal medulla. Neurosci Lett 273, 17-20

Ingvartsen KL, Andersen JB (2000) Integration of metabolism and intake regulation: a review focusing on periparturient animals. J Dairy Sci 83, 1573-1597

Iqbal J, Henry BA, Pompolo S, Rao A, Clarke IJ (2003) Long-term alteration in bodyweight and food restriction does not affect the gene expression of either preproorexin or prodynorphin in the sheep. Neuroscience $118,217-226$

Kuhla B, Kuhla S, Rudolph PE, Albrecht D, Metges CC (2007) Proteomics analysis of hypothalamic response to energy restriction in dairy cows. Proteomics 7, 3602-3617

Kuhla B, Kucia M, Görs S, Albrecht D, Langhammer M, Kuhla S, Metges CC (2010) Effect of a high-protein diet on food intake and liver metabolism during pregnancy, lactation and after weaning in mice. Proteomics $10,2573-2588$

Law RA, Young FJ, Patterson DC, Kilpatrick DJ, Wylie AR, Mayne CS (2009) Effect of dietary protein content on animal production and blood metabolites of dairy cows during lactation. J Dairy Sci 92,1001-1012 
Lee K, Li B, Xi X, Suh Y, Martin RJ (2005) Role of neuronal energy status in the regulation of adenosine 5 '-monophosphate-activated protein kinase, orexigenic neuropeptides expression, and feeding behavior. Endocrinology 146, 3-10

Livak KJ, Schmittgen TD (2001) Analysis of relative gene expression data using real-time quantitative PCR and the 2(-Delta Delta C(T)) Method. Methods 25, 402-408

Nambu T, Sakurai T, Mizukami K, Hosoya, Yanagisawa M, Goto K (1999) Distribution of orexin neurons in the adult rat brain. Brain Res 827, 243-260

Minokoshi Y, Shiuchi T, Lee S, Suzuki A, Okamoto S (2008) Role of hypothalamic AMP-kinase in food intake regulation. Nutrition $24,786-790$

Mohamed T, Oikawa S, Iwasaki Y, Mizunuma Y, Takehana K, Endoh D, Kurosawa T, Sato H (2004) Metabolic profiles and bile acid extraction rate in the liver of cows with fasting-induced hepatic lipidosis. J Vet Med A Physiol Pathol Clin Med 51, 113-118

Oikawa S, Oetzel GR (2006) Decreased insulin response in dairy cows following a four-day fast to induce hepatic lipidosis. J Dairy Sci 89, 2999-3005

Ndibualonji BB, Dehareng D, Debue P, Godeau JM (1992) Determination of free amino acids in bovine plasma. Ann Med Vet 136, 413-422

Qi, Y, Iqbal J, Oldfield JB, Clarke IJ (2008) Neural connectivity in the mediobasal hypothalamus of the sheep brain. Neuroendocrinology 87, 91-112

Sarruf DA, Yu F, Nguyen HT, Williams DL, Printz RL, Niswender KD, Schwartz MW (2009) Expression of peroxisome proliferator-activated receptor- $\gamma$ in key neuronal subsets regulating glucose metabolism and energy homeostasis. Endocrinology 150, 707-712

Sartin JL, Dyer C, Matteri R, Buxton D, Buonomo F, Shores M, Baker J, Osborne JA., Braden T, Steele B (2001) Effect of intracerebroventricular orexin-B on food intake in sheep. J Anim Sci 79, 1573-1577

Vierling, R (1957) Anatomy of the hypothalamus nuclei nucleus supraopticus and nucleus paraventricularis in cattle and sheep. Anat Anz 104, 157-182 [in German]

Wiesner G, Morash BA, Ur E, Wilkinson M (2004) Food restriction regulates adipose-specific cytokines in pituitary gland but not in hypothalamus. J Endocrinol 180, R1-6

Xue B, Kahn BB (2006) AMPK integrates nutrient and hormonal signals to regulate food intake and energy balance through effects in the hypothalamus and peripheral tissues. J Physiol 574, 73-83

Zheng H, Patterson LM, Berthoud HR (2005) Orexin-A projections to the caudal medulla and orexin-induced c-Fos expression, food intake, and autonomic function. J Comp Neurol 485,127-142

Zieba DA, Kirsz K, Molik E, Romanowicz K, Wojtowicz AK (2011) Effects of orexigenic peptides and leptin on melatonin secretion during different photoperiods in seasonal breeding ewes: an in vitro study. Domest Anim Endocrinol 40,139-146

Received 11 May 2011, accepted 29 July 2011.

Corresponding author:

Björn Kuhla

email: b.kuhla@fbn-dummerstorf.de

Research Unit Nutritional Physiology »Oskar Kellner«, Leibniz Institute for Farm Animal Biology (FBN), WilhelmStahl-Allee 2, 18196 Dummerstorf, Germany 